\title{
Review of Hemerobiidae (Insecta:Neuroptera) from Egypt, with a new record
}

\author{
Hayam El Hamouly and Rabab F. Sawaby \\ Department of Entomology, Faculty of Science, Ain Shams Univ., Abbassia-Cairo, Egypt \\ elhamouulyy@hotmail.com \\ rababsawaby@sci.asu.edu.eg - rabab_sawaby@yahoo.com
}

\begin{abstract}
The Egyptian fauna of family Hemerobiidae (Neuroptera) is reviewed. Three species belonging to two genera; Wesmaelius (Kimminsia) navasi (Andreu, 1911), Wesmaelius (Kimminsia) nervosus (Fabricius, 1793) and Sympherobius (Sympherobius) fallax Navas, 1908 are recognized, with the first species is a new record for the Neuroptera fauna of Egypt. Male genetalia of $W$. navasi and $W$. nervosus are dissected and photographed. A key to Egyptian taxa is included together with color images. Synonyms, diagnoses, specimen examined and distributional data are also given.
\end{abstract}

Key words: Brown lacewing, Hemerobiidae, Neuroptera, predators, distribution, new record.

\section{INTRODUCTION}

Family Hemerobiidae or brown lacewing is the third largest family within order Neuroptera; suborder Hemerobiiformia. It is represented by approximately 600 species worldwide (Oswald, 2004; Farahi et al., 2009). Brown lacewings are small to medium-sized insects, easily recognized by their pale brown, frequently cryptic coloration, moniliform antennae, and wings held rooflike over the abdomen when resting (Monserrat, 2002).

Members of this family are similar to green lacewings (Family: Chrysopidae) but usually smaller, brown, membranous wings usually more rounded and covered with small hairs. Most brown lacewings are aphidophagous predators, usually having a narrow host range compared to green lacewings. They play a role in biological control, being more effective at low aphid densities than green lacewings as adults of these insects do not need to feed on honey dew to lay eggs. The low temperature of brown lacewings also gives them a survival advantage during cold spells and frosts in temperate climates (Neuenschwander et al. 1975; Kovanci et al. 2014).
Females of brown lacewings lay eggs, usually singly or in small groups. There are three larval instars and larval development needs about 15-20 days for completion. Larvae are active predators with broad bodies and curved, impressive mandibles used to catch and suck up body fluids from soft-bodied, phytophagous insects. Pupation occurs in a small silk capsule (Monserrat, 2002).

Currently, Hemerobiidae is divided into nine subfamilies; Drepanepterginae, Megalominae, Microminae, Carobiinae, Zachobiellinae, Drepanacrinae, Notiobiellinae, Hemerobiinae and Sympherobiinae (Orduna et al. 2016). Only the last two subfamilies are represented in the Egyptian fauna (El Hamouly \& Fadl, 2011).

Navas (1926) recorded only one species, Hemerobius nervosus Fabricius from Egypt. Since then, no detailed study has been conducted on the Hemerobiidae fauna in Egypt. So the present work was intended to clarify the taxonomic status of family Hemerobiidae in the Egyptian fauna.

\section{MATERIALS AND METHODS}

Hemerobiid specimens for this study are preserved in the following main 
Egyptian reference collections: Ain Shams University Collection, Faculty of Science (ASUC); Cairo University Collection, Faculty of Science (CUC) and Ministry of Agriculture Collection, Plant Protection Institute, Identification section (MAC). General terminology and the diagnosis of female genitalia follow Makarkin (1995 \& 1996). Male genitalia were placed in a solution of $10 \% \mathrm{KOH}$ at room temperature for about 10-15 minutes to remove soft tissue, then rinsed and dissected in $75 \%$ ethanol with drops of glycerin.Colored images were taken by a digital camera (Sony Dsc-W610).

\section{RESULTS AND DISCUSSION}

Family Hemerobiidae Latreille, 1802

Hemerobini Latreille, 1802.

Type genus: Hemerobius Linnaeus, 1758.

Hemerobiidae Westwood, 1838.

Hemerobiidae Latreille: Oswald, 1993.

\section{Diagnostic characters:}

Small brown or brownish insects, $6-15 \mathrm{~mm}$ in length. Compound eyes well developed, ocelli absent. Antennae elongated, moniliform with an enlarged basal segment. Pronotum generally transverse, wider than long, usually with a pair of obvious calli. Wings subequal; forewing length 3-18mm., R1 and RS fused for a long distance, Rs with two or more branches arising from the apparently fused stems of R1 and Rs, Sc and R not fused apically, costal veinlets always numerous and usually forked, most cross veins are in gradate series, $M$ and $C U$ forked near the base of the wing, R1 appears to give off a series of two or more separate radial sectors. Abdomen with10 segments, genitalia of both sexes give good specific characters, ovipositor not exerted.

\section{Key to Egyptian taxa of Hemerobiidae}

1- Forewing with 3 to 5 radial sectors (Fig. 1a); male ectoproct ending with ventral or lateroventral pointed process................
......Hemerobiinae (Genus Wesmaelius

Kruger)...............................2

- Forewing with 2 radial sectors (Fig. 1b); male ectoproct with one - three digitiform processes of varying length and curvature (Fig. 1c) Sympherobiinae (Sympherobius fallax Navas)

2- Longitudinal veins of forewing pale with fine brownish strips (Fig. 1d); female subgenitalia with relatively long lateral lobes and without paired additional plates; male terminalia, gonarcus and parabaculum as in Figs (1e1h)....................W. navasi (Andreu) - Longitudinal veins of forewing with dark and yellow strips (Figs. 1a \& 2a); female subgenitalia are markably broad with paired minute additional plates; male terminalia, gonarcus and parabaculum as in Figs $(2 b-2 f)$

W. nervosus (Fabricius)

Subfamily Hemerobiinae Latreille, 1802 Hemerobini Latreille, 1802.

Type genus: Hemerobius Linnaeus, 1758.

Hemerobiinae Latreille: Oswald, 1993.

Genus Wesmaelius Kruger, 1922

Wesmaelius Kruger, 1922.

Type species: Hemerobius concinnus

Stephens, 1836.

Kimminsia Killington, 1937.

Type species: Hemerobius betulinus

Strom, 1788.

Wesmaelius Kruger: Oswald, 1993.

\section{Diagnosis:}

Forewings broad with rounded or slightly pointed apex, recurrent vein long, subcostal area narrow, with one basal or one apical cross vein between $\mathrm{Sc}$ and $\mathrm{R}$, Rs normally with 3-4 branches, $\mathrm{CuA}$ pectinately branched, $\mathrm{CuP}$ forked only at margin, A1 long with several branches, A2 branched at its beginning, A3 simple, inner gradate series of crossveins (Gr1) short, with 3-4 crossveins, intermediate series (Gr2) usually with 4-5 cross veins, outer series (Gr3) usually with 6-8 cross veins. 


\section{Review of Hemerobiidae (Insecta:Neuroptera) from Egypt, with a new record}

Male genitalia: Tergit 9 expanded at ventral side. Ectoproct ending with ventral or lateroventral pointed process. Sternite 9 rather narrow. Gonarcus arch like. Parabaculum fused basally with pointed posterior apex and with two dorsal broad lobes.

Female genitalia: Tergite 8 narrow, bandlike, rounded ventrally. Tergite 9 expanded ventrally. Subgenitalia well developed, of various size and shape, with mostly separated lateral lobes. Ectoproct more or less rounded, oval or triangular with rounded angles. Gonocoxites 9 semi-oval or semi-rounded. Seminalduct bag-like.

Remark: Aspock et. al. (1980) subdivided the genus Wesmaelius Kruger, into 2 subgenera Wesmaelius Kruger, 1922 and Kimminsia Killington, 1937. Klimaszewski and Kevan (1987) diagnosed Wesmaelius based on four main characters: forewing broadly oval, with $2 \mathrm{ir}$ crossvein present, ectoproct of male triangular in shape, and $9^{\text {th }}$ gonocoxites of female elongate. While the subgenus Kimminsia was characterized by forewing narrowly oval with 2 ir crossvein absent, ectoproct of male rectangular in shape, and $9^{\text {th }}$ gonocoxites of female short. This subdivision has been widely accepted. Only subgenus Kimminsia is presented by two species in Egypt.

Wesmaelius (Kimminsia) navasi (Andreu, 1911) (New species record) (Figs. 1d-1h)

Boriomyia navasi Andreu, 1911.

Boriomyia persica Morton, 1921.

Kimminsia neimenica Yang, 1980.

Wesmaelius (Kimminsia) navasi

(Andreu): Makarkin, 1996.

\section{Diagnostic characters:}

Body length $5 \mathrm{~mm}$ with pale hairs.

Head entirely yellow with no brown spots between antennal base. Antennae yellow. Pronotum yellow with a short indistinct brownish median stripe anteriorly, lateral border pale brown. Mesothorax and metathorax yellow with pale brown bands. Forewing $6.8 \mathrm{~mm}$. long, pale yellowish, Gr1 with 3 crossveins, Gr2 with 5 cross veins, Gr3 with 6 crossveins. An obvious spot occurs around the crossvein m-cua in inner gradient. Longitudinal veins pale yellowish with fine brownish interruptions. Crossveins partly pale. Hindwing $6 \mathrm{~mm}$. long, yellowish, with veins pale, partly brownish. Legs pale yellowish, femora dark outside, fore and middle tibiae with brown spots. Abdomen yellowish with pale yellowish hairs.

Male genitalia: ectoproct rectangular in shape, with heavy long hairs in the inner lateral side,ventral process dark brown, short and pointed apically; gonarcus with arched and stout paramediuncus; mediuncus short; parabaculum arrow-like in dorsal view and comma shape with bulging part at middle in lateral view.

World distribution: Spain, Greece, Malta, Morocco, Tunis, Egypt, Saudi Arabia, Palestine,Turkey, Lebanon, Iraq, Pakistan and Iran.

\section{Specimen examined:}

Locality only listed as Egypt, (1 male) (MAC). Cairo 7.12.1918 (2 males) (ASUC).

Wesmaelius (Kimminsia) nervosus

(Fabricius, 1793) (Figs. 1a \& 2a-2f)

Hemerobius nervosus Fabricius, 1793.

Hemerobius frostinus Navas, 1933.

Kimminisia cinerea Nakahara, 1960.

Kimminsia alexanderi Nakahara, 1965.

Kimminsia acuminate Yang, 1980.

Wesmaelius (Kimminsia)nervosus

(Fabricius): Makarkin, 1996

\section{Diagnostic characters:}

Body length $5 \mathrm{~mm}$. Face brownish yellow. Vertex pale yellow with four dark spots. Antennae entirely brownish yellow. Pronotum brownish with lateral border dark brown. Mesothorax and metathorax yellowish with lateral dark stripes. Fore 
wing $7 \mathrm{~mm}$. long, Gr1 with 3 crossveins, Gr2 with 5 crossveins and Gr3 with 6 crossveins. Longitudinal veins with dark and yellow strips. Conspicuous dark brown spots occurring around the crossveins m-cua of $\mathrm{Gr} 2$ and crossveins of cubital area. Cross veins dark colored. Hind wing $6.5 \mathrm{~mm}$. long with longitudinal and pale crossveins. Legs yellowish with darker apical joints of tarsi. Fore and middle tibiae with two distinct dark spots outside. Abdomen dark brown with heavy elongated yellow hairs.

Male genitalia: ectoproct rectangular in shape, with heavy long hairs in the inner lateral side, ventral process dark brown, extended and pointed apically; gonarcus with arched, elongated and stout paramediuncus; mediuncus prolonged; parabaculum arrow-like in dorsal view and comma shaped in lateral view.

World distribution: Iran, China, Japan, Armenia, Canada, USA and Egypt.

\section{Specimen examined:}

Cairo 12.11.1918 (1) (ASUC). Wadi El Ratba S. Sinai 24.4.40 (2), Wadi El Arbeine S. Sinai 24.4.40 (2), Wadi El Lega S. Sinai 20.4 .39 (4) (CUC). Meadi 26.3.1913 (1), 5.5.1918 (3), 30.9.1918 (1); Cairo 11.2.1918 (1); Wadi El Natroun 29.2.1923 (2); Sant Kathrin 28.5.1935 (2); Locality only listed as Egypt (5) (MAC).

Subfamily: Sympherobiinae Comstock, 1918 Sympherobiidae Comstock, 1918. Type genus: Sympherobius Banks, 1904. Sympherobiinae Comstock: Oswald, 1993.

Genus Sympherobius Banks, 1904 Sympherobius Banks, 1904.

Type species:

Hemerobius amiculus Fitch, 1854.

Spadobius Needham, 1905.

Hemerobius occidentalis Fitch, 1854. Sympherobius amicus Navas, 1915 a.

Sympherobius Banks: Oswald, 1993.

\section{Diagnosis:}

Forewings broad with rounded apex; costal area nearly simple or very narrow, Rs normally with two branches, $\mathrm{CuP}$ not forked proximal to crossvein 2cua-cup, inner gradate series of crossveins (Gr1) short, with 3-4 crossveins, intermediate series $(\mathrm{Gr} 2)$ usually with 5-6 crossveins, outer series (Gr3) usually with 4 or lesscrossveins arranged into two groups, MP and MA connected by a cross vein shortly after the origin of former.

Male genitalia: Ectoproct bearing one three digit form processes of varying length and curvature, usually pointed or armed apically. Callus cercus with trichobothria. Sternite 9 elongated into a long finger-like process.

Female genitalia: $8^{\text {th }}$ tergite with lateral ends widely separated, adjacent or fused ventrally. $9^{\text {th }}$ tergite expanded ventrally. Subgenitalia small, oval or subrectangular, posterior margin sometimes emarginate. Seminal duct long and well sclerotized.

Note: this genus comprises two subgenera: Sympherobius Banks, 1904 and Niremberge Navas, 1909. Only the first subgenus is represented in the Egyptian fauna.

Sympherobius (Sympherobius) fallax

Navas, 1908 (Figs. 1b \& 1c-2g \& 2h)

Sympherobius fallax Navas, 1908.

Sympherobius amicus Navas, 1915a.

Nefasitus amicus Navas, 1915b.

Sympherobius fallax Navas: Monserrat, 2008.

Sympherobius fallax Navas: El Hamouly \& Fadl, 2011.

\section{Diagnostic characters:}

Body length $3 \mathrm{~mm}$. Vertex pale yellow. Antennae brownish yellow. Pronotum brownish. Legs yellowish. Fore wing length $5 \mathrm{~mm}$, Gr1 with 3 crossveins, 
Review of Hemerobiidae (Insecta:Neuroptera) from Egypt, with a new record

Gr2 with 5 crossveins and Gr3 with 4 crossveins. Longitudinal veins yellowish with short brownish interruptions. Crossveins dark. Hind wing $4 \mathrm{~mm}$. long with longitudinal palecross veins. Abdomen brownish with sparse white long hairs.

Male genitalia: ventrolateral ectoproct process biforked apically, dorsolateral and ventromedial ectoproct processes pointed apically; pseudomediuncus bipartite.

World distribution: Saudi Arabia, Egypt, Palestine, Lebanon, Turkey, Spain, Greece, Sudan, Ethiopia and Morocco.
Specimen examined:

Cairo 8.10.1918 (1), 13.10.1918 (1), 28.10.1918 (2), 9.11.1918 (1), 12.11.1918

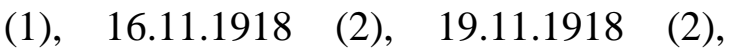
$23.11 .1918 \quad$ (3), $25.11 .1918 \quad$ (2), 26.11.1918 (2), 5.12.1918 (1), 19.12.1918 (1), 24.12.1918 (1), 25.12.1918 (1), 18.2.1922 (1); Embaba 5.11.1920 (3), 8.11.1920 (1), 10.11.1920 (1), 16.11.1920 (2); Gezirah 4.11.1920 (2); Girga 12.11 .1920 (1); Meadi 8.9.1918 (1), 24.9.1918 (1), 30.9.1918 (3);Giza 9.2008 (7);Locality only listed as Egypt (35) (MAC). Ain Shams 8.2017 (1) (ASUC).

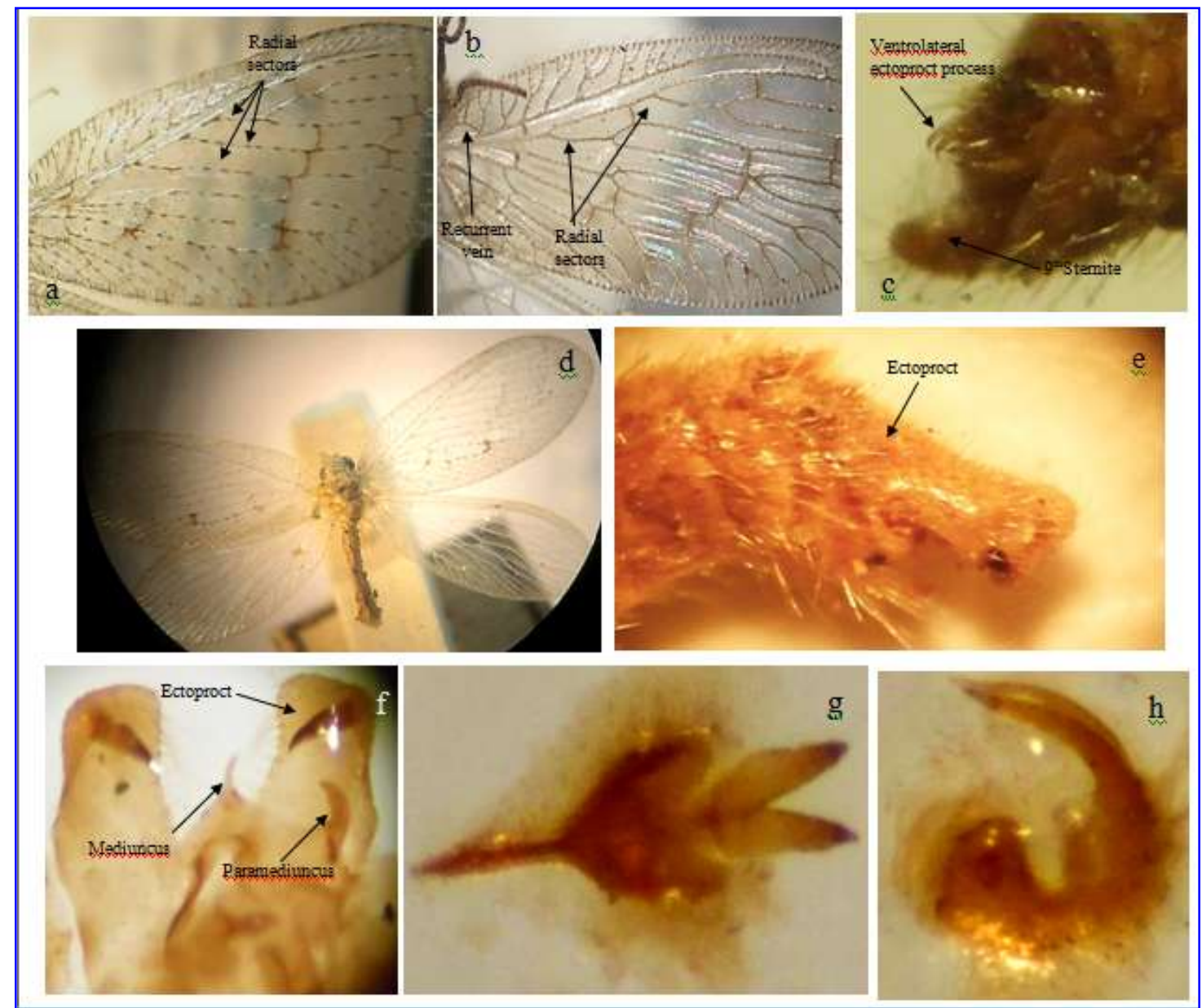

Fig. 1: a. Wesmaelius nervosus (Fabricius) forewing; b. \& c. Sympherobius fallax Navas: b. Forewing, c. Male terminalia, lateral view; d-h. Wesmaelius navasi (Andreu): d. Habitus, e. Male terminalia, lateral view, f. Gonarcus, dorsal view; g. Parabaculum, dorsal view, h. Parabaculum, lateral view. 
Hayam El Hamouly and Rabab F. Sawaby

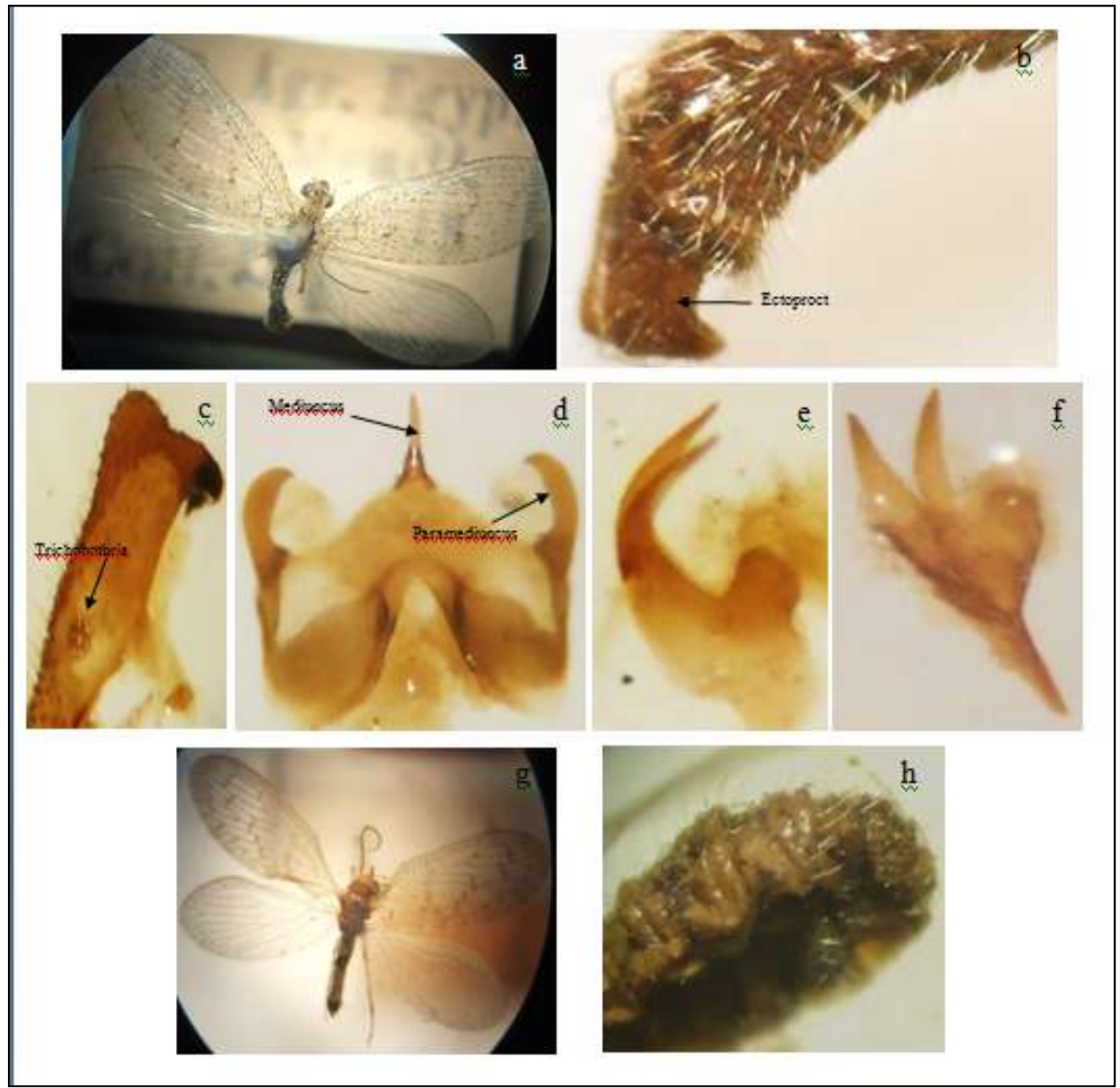

Fig. 2: a-f. Wesmaelius nervosus (Fabricius): a. Habitus, b. Male terminalia, lateral view, c. Ectoproct, caudal view, d. Gonarcus, dorsal view, e. Parabaculum, lateral view, f. Parabaculum, dorsal view; g. \& h. Sympherobius fallax Navas: g. Habitus, h. Abdomen, lateral view.

\section{Acknowledgements}

Our grateful thanks are passed to Dr. Vladimir N. Makarkin, Institute of Biology and Pedology, Far Eastern Division of the Russian Academy of Sciences, for his valuable help.We are also grateful to the staff members of the Entomology Department, Faculty of Science, Ain Shams University, to the staff members of the Faculty of Science, Cairo University and to the Ministry of Agriculture collection, Plant Protection Institute, Identification section for their kind help.

\section{REFFRENCES}

Andreu, J. (1911). Neuropteros de la provincia de Alicante. Unaespecienueva. Bol. Soc. Aragon. Cienc. Natur. 10: 56-59.

Aspock, H.; Aspock, U. and Holzel, H. (1980). Die Europas Einezusammenfassende arstellung der Systematic, Okologie und Chorologie des Neuropteroidea (Megaloptera, Raphidiootera, Planipennia) Europas Krefeld: Goecke \& Evers Vol. 1, 495 pp.; Vol. 2, 355 pp. 


\section{Review of Hemerobiidae (Insecta:Neuroptera) from Egypt, with a new record}

Banks, N. (1904). A list of neuropteroid insects, exclusive of Odonata, from the vicinity of Washington, D.C.: Proc. Entomol. Soc. Wash., 6: 201217.

Comstock, J. H. (1918). The wings of insects. Comstock Publishing Company, Ithaca, New York, xviii: 430pp.

Cutright, C. R. (1923). Life history of Micromus posticus Walker. J. Econ. Entomol., 16: 448-456.

El-Hamouly, H. and Fadl, H. H. (2011). Checklist of Order Neuroptera in Egypt, with a key to families. African Journal of Biological Science 7, 85-104.

Fabricius, J. C. (1793). Entomologica Systematica, etc. Vol. 2. Hafniae. VIII +520pp.

Farahi, S.; Sadeghi, H. and Whittington, A.E. (2009). Lacewing (Neuroptera: Chrysopidae \& Hemerobiidae) from north eastern and east provinces of Iran. Munis Entomol. \& Zool., 4: 501-509.

Fitch, A. (1854). Report[upon the noxious and other insects of the State of New York. Trans. N. Y. State Agric. Soc. 14: 705-880.

Holzel, H.; P. Ohm and P. Duelli (1999). Contribution to the knowledge of the Neuroptera of Ethiopia. Entomofauna, 20: 345-372.

Killington, F. J. (1937). A monograph of British Neuroptera. Vol. 2. London:Ray Soc., 123: 306 pp.

Klimaszewski, J. and Kevan, D. K. McE. (1987). The brown lacewing flies of Canada and Alaska (Neuroptera; Hemerobiidae). Part II. The genus Wesmaelius Kruger. Neuropt. Int. 4: 153-204: 245-274.

Kovanci, O. B.; Canbulat, S. and Kovanci, B. (2014).The brown lacewings (Neuroptera, Hemerobiidae) of northwestern Turkey with new records, their spatio-temporal distribution and harbouring plants.
Rev. Brasileira Entomol., 58(2): 147-156.

Krüger, L. (1922). Hemerobiidae. Beiträgezueiner Monographie der Neuropteren - Familie der Hemerobiiden. StettinerEntomol. Zeit., 83: 138-172.

Latreille, P. A. (1802). Histoire naturelle, generaleetparticuliere de Crustaces et des Insectes. Vol. 3. Dufart, Paris. 467 pp.

Linnaeus, C. (1758). Systemanatura per regna trianaturaesecundum classes, ordines, genera, species, cum characteribus, differentiis, synonymis, locis. $10^{\text {th }}$ Ed. Vol. 1 . Salvii, Hol-miae. 824 pp.

Makarkin, V. N. (1995): Notes on Palearktic Hemerobiidae (Neuroptera). I. Introduction and genus Wesmaeleus Kruger, 1922. Part 1. Subgenus Wesmaeleus. Far East. Entomol., 24: 1-13.

Makarkin, V. N. (1996). Notes on Palearktic Hemerobiidae (Neuroptera). I. Introduction and genus Wesmaeleus Kruger, 1922. Part 2(1). Subgenus Kimminsia Killington 1937. Far East. Entomol., 31: 1-16.

Makarkin, V. N. (1996). Notes on Palearktic Hemerobiidae (Neuroptera). I. Introduction and genus Wesmaeleus Kruger, 1922. Part 2(2). SubgenusKimminsia Killington $1937 . \quad$ Far East. entomol. 32: 17-34.

Macleod, G. E.and Stange, A. L. (2014). Brown Lacewings (of Florida) (Insecta: Neuroptera: Hemerobiidae). http:// entomology.ifas.ufl.edu/creatures.

Monserrat, V. J. (2002). Family Hemerobiidae. Proc. California Acad. Sci., 53(12): 238-418.

Monserrat, V. J. (2008). Nuevosdatossobre algunas especies de Hemerobidos (Insecta, Neuroptera, Hemerobiidae). Graellsia, 64(2): 233-253. 


\section{Hayam El Hamouly and Rabab F. Sawaby}

Morton, K. J. (1921). Neuroptera, Mecoptera and Odonata from Mesopotamia and Persia. Entomol. Mon. Mag., 57: 213-222.

Nakahara, W. (1960). Systematic studies on the Hemerobiidae. Mushi, 34 (1):1-69.

Nakahara, W. (1965). Contributions to the knowledge of the Hemerobiidae of Western North America (Neuroptera). Proc. U.S. Nat. Mus., 116 (3503):205-222.

Navas, L. (1908). Neuropteros de Espana y Portugal. Broteria (Zoologica) 7: 5131.

Navas, L. (1909). Neuropteros de los alrededores de Madrid. Suplemento 1. Rev. R. Acad. Cienc. Exactas Fis Nat. Madr. 8: 370-380.

Navas, L. (1915a). Appendice. In: SILVESTRI, F., Contributoallaconoscenzadegli insetti dell' olivodell' Eritrea e dell' Afncameridionale.

Bollettinodello Laboratorio de Zoologia Generale e Agraria, Portici 9: 263-333.

Navas, L. (1915b). Neuropterosnuevos o pococonocidos, 6. Serie. Memorias de la Real Academia de Ciencias y Artes de Barcelona 12: 118-136.

Navas, L. (1926). Insectaorientalia. IV series. Mem. Accad. pont. NuoviLincei (2) 9:111-120.

Navas, L. (1933).Neurotteri e Tricotteri del "Deutsches Entomologisches Institut" di Berlin-Dahlem. - Boll. Soc. Entomol. Ital., 65: 105-113.

Needham, J. G. (1905). The summer food of the Bullfrog (Rana catesbiana) at Saranac Inn. Pp. 9-17 in May Flies and Midges of New York, Third Report on Aquatic Insects, J. G. Needham, K. J. Morton, and O.A. Johannsen. N.Y. St. Mus., Bull. 86 (Entomology 23), 352 pp.

Neuenschwander, P.; Hagen, K.S. and Smith, R.F. (1975). Predation on aphids in California's alfalfa fields. Hilgardia, 43: 53-78.

Orduna, I. J.; Armenta, I.M.; Ramos, A.C.; Liu, X. and Winterton, S.L. (2016). The phylogeny of brown lacewings (Neuroptera: Hemerobiidae) reveals multiple reductions in wing venation. BMC Evolutionary Biology BMC series-open, inclusive and trusted 16: 192. https://doi.org/10.1186/s12862016-0746-5

Oswald, J. D. (1993). Revision and cladistic analysis of the world genera of the family Hemerobiidae (Insecta: Neuroptera). J. New York Entomol. Soc., 101: 143-299.

Oswald, J. D. (2004). Review of the brown lacewing genus Biramus (Neuroptera: Hemerobiidae: Hemerobiinae), with the description ofa new species from Costa Rica and Panama. Tijdschriftvoor Entomol., 147: 4147.

Stephens, J. F. (1836). Illustrations of British Entomology. Vol. 6. Mandibulata. Baldwin \& Cradock Publ., London: 240pp.

Strom, H. (1788). Nogle insect larver med deresforvandlinger. Nye Samlingafdet Kongelige Norske Videnskabers Selskabs Skrifter, Kobenhaven 2:375-400c.

Westwood, J. O. (1838). Order V. Neuroptera Linn. Pp. 46-48 in Synopsis of the genera of British insects. London. 154 pp. (Dating: From International Commission on Zoological Nomenclature, Direction 63.) (1838-1840, November)

Yang, C. K. (1980). Some new species of the genera Wesmaelius and Kimminsia (Neuroptera: Hemerobiidae). - Act. Entomol. Sinica, 23(1): 54-65. 
Review of Hemerobiidae (Insecta:Neuroptera) from Egypt, with a new record

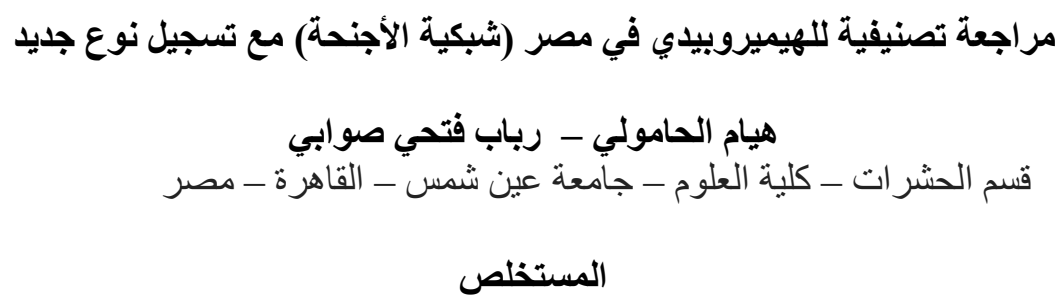

من خلال الدر اسة الحالية تمت المر اجعة التصنيفية لفصيلة الهيميروبيدي (شبكية الأجنحة) في مصر . وقد تبين وجود ثلاثة أنواع تتنمي الي جنسين وهم: ويزميلاس (كبينسيا) نافازي (أندريو) - ويزميلاس (كبينسيا) نبرفوسبس (فابريشيس) وأيضا سيفروبيس (فالكس) فالكس نافاز مع العلم أن النوع الأول يسجل لأول مرة في مصر. أيضا نم تشريح وتصوير الأعضاء التناسلية الذكرية للأنواع وبزميلاس (كبينسيا) نافازي (أندريو) - وبيزمبلاس (كبينسيا) نبرفوسبس (فابريشيس). بالأضافة الي ذلك تم عمل مفاتيح تصنيفية للأنواع المصرية مزودة بالصور الملونة ونم أدراج التوزيع الجغر افي لهذه الأنواع. 